\title{
6. Food and Transnationalism: Reassertions of Pacific Identity
}

\section{Nancy Pollock}

Food reinforces ties between Pacific peoples and their island homes, while linking them to a wider world. Food globalises while it localises, thereby crossing national boundaries. It links families through exchanges and shared ideologies and diversifies over time and space. Increased options of foods from the land or from the supermarket are part of that diversity. Brands such as McDonalds and Coca-Cola are 'not the tip of some globalizing iceberg, but rather the markers of a particular superordinate level of identity on a par with saving the rainforest' (Miller 1997, 80). Food is an identity marker that both links families overseas to their island home and distinguishes the two communities.

This paper aims to demonstrate that mobile communities have carried their gastronomies with them across space and time, modifying them according to social and environmental dictates. The cultural values embodied in these gastronomies have been subject to a number of influences that can be captured in three 'foodscapes'. Foodscapes, I argue, are additional to Appadurai's ethnoscapes, which he sees as 'the landscape of persons who constitute the shifting world in which we live: tourists, immigrants, refugees, exiles, guest workers and other moving groups and individuals who constitute an essential feature of the world...' $(1996,33)$. Mediascapes, technoscapes, financescapes and ideoscapes, plus foodscapes, indicate 'irregular shapes, imagined in their complexity, and the product of deeply perspectival constructs' (ibid, 33). Perspectives on foodscapes allow us to depict the mobilisation of cultural differences in the service of a larger national or transnational politics' (ibid., 15). They have a place in the construction of insights into this 'shifting world' of modernity and identity (ibid, 33).

Throughout history people have been transferring their foodways as they move across land and sea, linking with the past as well as considering novel food choices. 'A historical overview is just as useful when looking at food and food systems as it is when considering globalisation as a whole...It is analytically useful to link up what is happening now to what has already happened' (Mintz $2006,4)$. Transnationalism offers an alternative approach to globalisation as it provides a focus on cultural distinctions. As populations spread, foods gain significance as much for their novelty as for their ties to the past. Foodscapes depict those historical and spatial links. 
Here, I contrast Pacific foodscapes that link Asian influences with modern influences emanating from a Euro/American background (often referred to as westernisation). The first oriental foodscape depicts the gastronomies of early voyagers as they established new communities with foodstuffs they carried with them. A more recent foodscape, largely post World War II, captures Asian gastronomic influences that recent Chinese communities have brought with them. The third set of influences, that stem from occidental ideologies, have led to a proliferation of western foods imported to the islands, as well as the options in supermarkets. All three foodscapes are blended to offer a range of options, whether in the form of taro chips or hamburger buns, each depicting interpretations of cultural identity.

Foodscapes represent different forms that gastronomies can take as a result of past and present influences. Brillat-Savarin introduced the term gastronomy through his focus on the many features of 'taste' as the key element of gastronomy: 'It examines the effect of food on man's character, his imagination, his wit, his judgement, his courage, and his perceptions...It is gastronomy which determines the point of esculence of every foodstuff, for they are not all palatable in identical circumstances' $(1970,53)$. While he depicts individual tastes, he provides a broader framework than just the material aspects of food. Modern gastronomy includes six key features that contribute to the depiction of a foodscape:

- foodstuffs in material form, their origins and diversity;

- food ideology that is manifest in how foods are used in eating situations and the values on which food use is based;

- specific food-associated events, such as preparation, cooking, preservation, eating, and feasts;

- $\quad$ social relationships in which food events are embedded;

- myths and legends associated with particular foods and food event (Pollock 2008).

A gastronomic framework is dynamic as it is challenged by new options that may be accepted, rejected, or adapted in some way, as exemplified by the Pacific custom of serving taro with fish, linking land and sea, or rice topped with instant noodles as a quick meal.

A transnational approach to gastronomies celebrates food as a means of cultural expression. It contrasts with a globalisation approach which stresses economic over other cultural concerns; Stiglitz has highlighted the need for alternatives to the homogenising capitalist approach to globalisation in which 'economic interests take precedence over other values, particularly cultural identity (2006, 129). He suggests that global approaches should support those discontented with the corporate interests that dominate trade and violate basic values such as 
heritage, language and a sense of cultural identity (ibid, 131). Foodscapes underline that respect for food in the enhancement of cultural identity.

An anthropological approach supports a transnational approach and is counter-intuitive to globalisation arguments. Significant differences between eastern and western gastronomies can be found in urban, rural and overseas communities. Resistance to innovations such as McDonalds and responses to body size as linked to 'over-eating' are two examples. As Miller's anthropological view of capitalism suggests 'anthropologists might argue that global institutions tend to look superficially similar wherever one finds them but if [they] are able to examine the evidence carefully they will find that underneath this façade of similarity may be discerned authentic differences' (1997, 14). Furthermore, he points out that 'institutions that generate new differences are just as important as new forms of homogeneity or old forms of separation' (ibid, 15). Tracing transnational influences through foodscapes enables us to highlight the cultural continuities and innovations, choices that communities make to enhance their identity.

\section{Oriental Influences - Earliest Settlements}

The earliest foodscape for the Pacific depicts many Asian and Chinese influences (Pollock 2008). Many starch plants entered the Pacific from Southeast Asia, thereby establishing strong gastronomic links with the island nations. Travellers shared a common Austronesian language (Bellwood 1997; Irwin 2006; Kirch 2000). Agricultural expansion began some 6,000 years ago, but accelerated 3,000 years ago as Lapita peoples spread across Oceania, according to Bellwood's (2005) farming/language dispersal hypothesis. This early oriental foodscape provides us with a significant time period against which to understand Pacific gastronomic patterns today.

The earliest settlers who moved out of southeast Asia across the Wallace Trench brought taro roots, coconuts and other foodstuffs, some to eat on the voyage, while saving the taro tops for planting at their new landfall (Allaby 2007; Pollock 1992; Walter and Lebot 2007). Other species of taro, yams, bananas and breadfruit were introduced by subsequent waves of settlers. This increased the diversity of local foods still in use today to ten starch foods, seven of which have a homeland in Taiwan and island Southeast Asia (Allaby 2007; Pollock 1992).

A major feature of oriental influences on gastronomy is the emphasis on the starch food as the dominant component of daily food intake, accompanied by a small portion of sauce or fish. The starch element was considered 'real food', termed kakana dina in Fijian and karan unun, in Hanunoo, Philippines (Conklin 1957; Pollock 1986). The combination of slices of taro or yam and a small amount of fish or piece of coconut as accompaniment we term a 'meal' in English, but that is a late European concept, as discussed below. 
These food plants depended on human agency for their dispersal and propagation, as they reproduce only by vegetal propagation. Subsequent waves of migrants brought new species, new varieties and new ideas, as revealed by botanists' reconstructions from DNA, along with archaeologists' findings of materials associated with plant production and historical linguists' study of early linguistic forms (Bellwood 2005; Blench 2005; Kirch 2000). The result has been the continuing diversification of gastronomies.

All these starch staples have to be cooked today, so we assume that earlier varieties also had to be cooked to make them edible. The earth oven was the means used to cook quantities of starch foods to last several days, and became men's work. Some foods such as breadfruit could be roasted in the coals of a fire in a shallow pit on the ground. Southeast Asian peoples have cooked their foods over such fires, as writers from Europe and America have shown (Yo 1995). Boiling necessitated pots, used in high status Chinese households to cook rice, but in the Pacific, Lapita pottery did not become available until about 1500 BC; whether those pots were used for cooking has not been definitely established (Green, personal communication, 2007). They may have been used only for high status family members and visitors. Such gastronomic reconstructions are tentative as they are inevitably based on contemporary values, both sociocultural and biological.

Sharing the starch and its accompaniment once a day between extended family households enabled one earth oven to feed 10-15 people. Ancestors were also offered food and drink (see Firth 1967) a practice considered vital to ensuring continuity of a food supply for the whole community. 'First fruits' ceremonies marked a community's acknowledgment of the importance of those ancestors in establishing a good food supply. Myths of the origins of food plants have perpetuated accounts of the movement of ancestral populations and the foods they brought with them.

This early foodscape depicts a strong gastronomic base that includes not only the foods themselves, but also modes of cooking and serving, and the ideology of food as the centre of sociality. These features mark a continuity with the southeast Asian homeland cultures (Bellwood 1997; Howe 2007). Subsequent introductions have been adapted and changed, but key features are still recognisable.

\section{Modern Oriental Influences}

Gastronomic links with Southeast Asia have been further strengthened with the settlement of Chinese and other Asian communities in the Pacific over the last 150 years. While national boundaries have become more distinct and barriers to food transfers have been erected in the form of import and agricultural regulations, rice and other oriental food habits have established a pervasive 
presence in Pacific households, whether in rural Samoa, an outlying island of Yap or metropolitan communities. Rice has been added to the food inventory as the centrepiece of many household foodscapes; rice is the hallmark of a transnational food.

Rice gained popularity in the Pacific after World War II as a cheap food, particularly for low-income urban communities. It can be served like the earlier starches, i.e. with a small accompanying dish such as grated coconut. It can be bought in bulk, stores readily, cooks reasonably quickly, fills and satisfies hungry adults and children, and thus is an ideal food for households on a small income.

Rice has its own gastronomic associations. It must be boiled and thus requires a special kind of fire, and a pot that will hold enough to feed large households. Boiling is women's work. Cooking it requires experience that female children learn early. Rice with warm sweet tea is the weaning food on outer islands of the Marshall Islands. Rice has not been acceptable as a feast food, except in Guam. It is an important aid food during environmental disasters as well as financial downturns. Rice has become important to island food security in the face of food shortages for both household and national economies (Pollock 2002).

Rice comprises a major proportion in both volume and cost of Pacific food imports, whether from the Philippines, Australia or the US (e.g. Tonga Trade statistics 2004). Attempts to reduce this dependency on imported rice have largely failed in the face of strong demand. Most urban centres in the Pacific have at least one Chinese takeaway shop that has contributed to a gastronomic profile based on rice. Chinese restaurants and takeaway food outlets, established in island urban centres, along with Indian curry houses, and Thai and other Asian-style eating places, offer different tastes in food. Some dishes, such as Samoan chop suey may be served at home, or during feasts, with recipes adapted to local tastebuds. Market gardens established by Chinese families in Tahiti and elsewhere have contributed fresh vegetables not formerly used in Pacific cuisine. Chinese food use is not necessarily associated with any particular aspect of oriental ideology; the foods have been adapted to blend with a Pacific foodscape.

While takeaway foods have become a global phenomenon, the small Asian restaurants provide a marked contrast to American corporate fast-food enterprises such as KFC and McDonalds. Asian restaurants reflect a change in attitudes to Asian immigrants and rely largely on their own family labour (for US examples, see Mintz 2006, 18). In 1993, Chinese migrant families moved to Nauru to establish 83 small businesses attached to Nauruan houses to cater for the fast-food needs of the media and other followers of the South Pacific Forum meetings held that year on Nauru. Many had to return to China after the Forum, but a few stayed to join the Chinese community on Nauru to sell cooked rice to Nauruans. Chinese takeaway restaurants offer similar/familiar dishes and tend to be cheaper 
than McDonalds, fried chicken and other fast foods that derive from a western influence. Both forms of fast foods have gained appeal among Pacific communities, whether in Suva or Auckland.

Japanese and Indian influences on gastronomy have not been as pervasive across the Pacific, despite their strong presence in the region. Nauruans recall being paid a match box of rice per day during the 1943-45 Japanese occupation of the island. Few Japanese or Indian restaurants have been established in urban centres, with the exceptions of Honolulu and Suva. Soy sauce and curry powder are two ubiquitous links to Asian gastronomies.

Oriental influences on Pacific gastronomies have been enduring as well as expanding. They extend beyond foodstuffs to the prevalence of the starch component, simple cooking styles, an emphasis on sharing with relatives and the community, respect for food, and its importance in spiritual rather than material wellbeing. A monetary economy supports Asian-style takeaway foods and restaurants, as well as supermarket offerings, and Chinese gardeners' produce. All reinforce Asian influences on today's Pacific gastronomies.

\section{Occidental Influences}

European and American influences on food habits and gastronomies reached the Pacific much later, i.e., only in the last 200 years. Traders, whalers, administrators and missionaries arrived with strong ideas about food and gastronomic practices. The earliest of these visitors such as Captain Cook exposed Pacific peoples to new foods and new gastronomies when they hosted chiefs on board their ships. They left plants and animals that they hoped would become established to supply victuals for future ships. Missionaries had a more pervasive influence as they lived alongside communities which they expected would adopt the new western gastronomic ways, as part of the civilising process (Pollock 1989). But Pacific communities were not so eager to replace their long-established eating and cooking habits with things that cost hard-earned money.

Only since World War II have many western gastronomic approaches proliferated. Western foodstuffs and ideologies spread as a result of aggressive marketing activity, rather than migrants' influences. An alternative use of 'transnationalism' to refer to the operations of large-scale multinational corporations is epitomised by reference to global food giants such as Nestle, Coca-Cola and McDonalds (see Miller 1997 with specific reference to Trinidad). Such companies vigorously sought to establish their products across the Pacific. Hot bread shops and fried chicken outlets represent these marketing principles, as do tuna processing and local beer and soft drink manufactures. These multinationals provided business models for creating new jobs as well as gastronomic opportunities. 
Commercial food outlets have proliferated, from small family-owned food stores to supermarkets, as Hau'ofa (1979) demonstrates for Tonga. Supermarkets located near the market place and bus depots became a social hub linking rural communities with their urban relatives (Pollock 1995). New gastronomic trends were passed on, including new recipes, new technology and new values of time and tastes associated with food. The desirability of the latest imports, recommended by visiting family members from New Zealand or Australia, has continued the process of widening gastronomic horizons.

Family responsibilities had to be rearranged as new gastronomic principles became accepted. Serving three meals a day, as missionaries recommended, interrupted work patterns, and cooking on a kerosene or electric stove became women's work. With men and young people away all day, others had to help with picking crops, cooking, feeding young children and washing clothes. Food parcels that travel both ways between Rarotonga and Auckland continue to express the love and affection that sustain family ties (Alexeyeff 2004). In urban centres, office workers buy their midday food at takeaway stores catering for these new needs.

Income has become a major determinant of what a household can put on the table. Cheap imports such as rice and canned fish were the limit for many households in the 1960s. Corned beef has become an icon of this new transnational trade in foodstuffs, as Michel Tuffery (2007) illustrates with his life-size cow sculptures made entirely from corned beef cans. He specifically links his art forms to his views as a New Zealand-born Samoan of the history of food exchanges that express Samoan identity across transnational boundaries (for an image see the Te Papa museum website).

New western ideas of gastronomy have introduced conflicting messages about the link between food and wellbeing. Missionaries advised housewives to feed their men meat, but this was not readily available in the islands until refrigerated transport was developed in the 1880s, and then the taste had to be acquired. Meat has always been more expensive than fish. A Pacific meal of taro eaten with fish remained the epitome of Pacific gastronomy because the components were readily available, filling, did not cost money and fulfilled long-established gastronomic ideals.

A repertoire of 'good foods', whether local or imported, has raised many questions, both for government officials and women's groups (see e.g., Schoeffel 1985). These new foods, promoted by the media, medical advisors and nutritionists were based entirely on western ideology and bio-medical reasoning. At first, they derogated Pacific gastronomic habits but these gained positive value for their high fibre, low salt and low sugar content, in contrast with western gastronomic habits that contributed to increased rates of cardiovascular problems and diabetes (Coyne, Badcock and Taylor 1984). Brenda Sio produced a Samoan 
food pyramid for World Food Day in Samoa 1996 which included Pacific foods alongside western foods differentiating the good labelled Ioe (yes) versus Leai (no) (Sio 1996); this proved a more effective nutrition education message than previous, monocultural ones. Obesity has emerged in the new millennium as a major health concern linked to poor food choices both in the islands and in overseas communities, as was demonstrated by a front cover story of Islands Business in March 2007.

Western gastronomic influences introduced a drastically new set of ideals and practices that became major commercial intrusions. But we must distinguish their introduction from their adoption. The new gastronomic principles could not override the identity that had become established between Pacific communities and their foodways inherited from their ancestors and established by migrants over several thousand years.

\section{Blendings}

Blending of old and new, island and metropolitan foods, messages from family and the media, advice about good food and image management all bombard present day consumers. Any search to maintain a Pacific identity through food choices becomes complex. Households choose foods according to a number of criteria that include previous influences and new opportunities. A study of decisions about food access for low income households around Wellington revealed a large gap between desires and realities, and greater problems for large Maori and Pacific island families. With only $\$ 100$ per week to spend on food, four factors dominated their choices: taste, time, health and cost. Foods had to suit family tastes, be quick to put on the table, be as healthy as possible and come within the budget. Fruit and vegetables and better cuts of meat were often too expensive. Sometimes McDonalds was the easy solution, though it took up a major part of the weekly food budget (Pollock, Dixon and Leota 1996). This survey alerts us to limitations to gastronomic options.

The gastronomic package reveals some of the alternative ways that blending is occurring. The foodstuffs, combinations, meals and eating situations, special food events and recognition of social relationships all form part of the messages and practices embedded in the presentation of identity through food.

Foodstuffs available in the Pacific today represent a long heritage of choosing varieties that suit tastes, seasonal availability and other local criteria. The concept of 'good food' is changing today, as it also did in the past. Taro is very expensive for everyday use in metropolitan households, as is fish when feeding a large group. Ice cream, cakes and desserts have intruded more into public eating occasions than ordinary daily meals. Coca-Cola and fried chicken have been heavily promoted by outside commercial agents and sweet biscuits are a grandmother's solution to soothing a little one - the label 'good' or 'bad' is not 
a consideration then. Agencies such as Fiji Food and Nutrition Committee and Pacific Islands Nutrition and Dietitians Association, together with the Food and Agriculture Organization, all offer guidance on best choices among foods available. But ultimately households use foods that fit their own gastronomic ideals.

Meals and eating situations are more diverse for urban communities, whether in Apia or Auckland. Meal times for family units compete with other activities. The 'ideal' combination of taro and fish may remain for older family members, while for younger members the fast foods, fruits and vegetables may suit their fitness image. Nutritionists' ideal meal of meat, vegetables and dessert may be too expensive or outside their identification. Distinctions between snack and meal foods depend on local interpretations, i.e. pizza might be either. Cooking styles may represent a blending, as when taro or fish is cooked in tinfoil in the electric oven; fried food, particularly chicken, has become highly favoured though nutritionally problematic, yet a highly acceptable gift when a family flies a 'chilly bin' full of KFC from Auckland to Rarotonga. A balanced meal has many dimensions in today's world. Feasts remain an opportunity, or challenge, for families to lay out their identity through their contributions of taro, raw fish, chicken and cakes.

Social relationships are strengthened and challenged by the blendings of old and new gastronomic principles, and by exchanges of food that express what Cook Island people call aro'a (Alexeyeff 2004, 76). Feasts are important times for socialising around food, with much thought and planning as to which families contribute particular foods. Fish and beef (including canned corned beef, pisupo in Samoan) are all expensive in metropolitan settings, as are taro and the other imported iconic foods. However, the social mores of giving override any economic considerations, so that a family may take out a loan to buy their food contributions. Individual food choices are a major departure from the sociality of sharing an umu, as in rural island communities, or sending food across the seas. Those individuals with money to buy their lunch develop personal food preferences that may differ markedly from family food preferences. But when they exercise those preferences, they distance themselves from their family and its cultural gastronomic values. Expectations of what a family should or can offer to a funeral feast undergo public scrutiny and comment. Upholding social obligations through food is a key feature of reconstituting communities, particularly in overseas settings.

Food messages, whether as myths from the past, or recipes and routes of access to favoured island foods, are replacing the canoe and oral traditions. The telephone, texting and art all provide media both for motivating the oral and visual and other gastronomic senses, and for educating a wider public. All these 
options further enhance the diversity that has marked gastronomic transfers across time and space.

Blending has resulted in Pacific societies developing their own identifying foods together with a distinctive gastronomy. Over time, new foods and new ways of using those foods have been added to the gastronomy, not substituted. Good food is symbolised for Tongans and Pohnpeians by yams while for Fijians it is taro/dalo, and in the Marshall Islands it is breadfruit. When these groups come together in a metropolitan setting such as Honolulu or Wellington, each participating group ensures that its particular food is represented. Pacifica meetings in Wellington became noted for the Cook Island 'mayonnaise' that their people contributed to a Pacific event. Each Pacific community has selected its distinctive gastronomic features to distinguish its specific identity.

\section{Conclusions}

Food habits and gastronomies have followed three major transits into the Pacific, two from the orient and one from the occident (Euro/American). Three foodscapes depict the links between Pacific gastronomies today and those of the past. The Asian influence is of long duration and deeply embedded in gastronomic principles such as the starch/accompaniment principle, as when taro should be served with fish, while modern influences such as canned foods from both west and east have added to the diversity of foods and their uses. Adaptations of principles, for example the foods appropriate and available to give at feasts, have been elaborated and have added to the diversity of choices available to households today. The commercial spread of so-called global foodstuffs, such as McDonald's, increases the diverse options available to individuals and households, but they are not a full substitute for island foods. Whether in Nuku'alofa or Sydney, constraints on food choices due to family ties, tastes and available cash challenge expressions of identity through food.

\section{References}

Allaby, R. 2007. Origins of plant exploitation in Near Oceania. A review. In Population genetics, linguistics and culture history in the south west Pacific, ed. J. S. Friedlaender, 181-98. Oxford: Oxford University Press.

Alexeyeff, K. 2004. Love food - exchanges and sustainability in the Cook Islands. Australian Journal of Anthropology 15: 65-80.

Appadurai, A. 1996. Modernity at large. Cultural dimensions of globalization. Minneapolis: University of Minnesota Press.

Bellwood, P. 1997. Prehistory of the Indo-Malaysian archipelago. Honolulu: University of Hawai'i Press. 
-. 2005 The farming/language hypothesis in the East Asian context. In The peopling of East Asia, ed. L. Sagart, R.Blench and A. Sanchez-Mazas, 1-25. London: Routledge Curzon Press.

Blench, R. 2005. From the mountains to the valleys: Understanding ethnolinguistics. In The peopling of East Asia, ed. L. Sagart, R. Blench, and A. Sanchez-Mazas, 31-50. London: Routledge Curzon Press.

Brillat-Savarin, J.-A. 1970 [1821] The Philosopher in the kitchen. Harmondsworth: Penguin.

Conklin, H. 1957. Hanunoo Agriculture. FAO Forestry Development Paper \#12, Rome.

Coyne, N, J. Badcock and R. Taylor. 1984. The effect of urbanisation and western diet on the health of Pacific island populations. SPC Technical Paper 186. Noumea.

Firth, R. 1967. The work of the gods in Tikopia. London: George Allen and Unwin.

Hau'ofa, E. 1979. Corned beef and tapioca. Development Studies Monograph 19. Canberra: The Australian National University.

Howe, K. (ed.) 2007. Vaka Moana. Auckland: David Bateman Press and Auckland War Memorial Museum.

Irwin, G. 2006. Voyaging and settlement. In Vaka Moana, ed. K. Howe, 59-74. Auckland: David Bateman Press and Auckland War Memoriam Museum.

Kirch, P. 2000. On the road of the winds. Berkeley: University of California Press.

Miller, D. 1997. Capitalism, an ethnographic approach. Oxford: Berg.

Mintz, S. W. 2006. Food, history and globalization. Journal of Chinese Dietary Culture 2 (1): 1-22.

Pollock, N. J. 1986. Food classification in Fiji, Hawaii and Tahiti. Ethnology 25 (2): 197-118.

- 1989. The early development of housekeeping and imports in Fiji. Pacific Studies 12 (2): 53-82.

—. 1992. These roots remain. Hawaii: The Institute for Polynesian Studies and University of Hawaii Press.

- 1995. Introduction. In The power of kava, ed. N. Pollock. Special issue of Canberra Anthropology 18 (1 \& 2): 1-19.

-. 2002. Vegeculture as food security for Pacific communities. In Vegeculture in eastern Asia and Oceania, ed. S. Yoshida and P. Matthews, 277-92. Osaka: Japan Center for Area Studies. 
- 2008. Chinese dietary influences in the Pacific. In Proceedings of the $10^{\text {th }}$ symposium of Chinese dietary culture, ed. J. Chou. Taiwan: Foundation of Chinese Dietary Culture.

Pollock, N. J. and D. Dixon, and J. Leota. 1996. Food decisions in Wellington low income households. Report to the Department of Social Welfare, Wellington.

Schoeffel, P. 1985. Dilemmas of modernisation in primary health care in Western Samoa. Social Science and Medicine 19 (3): 209-16.

Sio, B. 1996. Taumafa Samoa mo le Lumanai 'Samoan Food for the Future'. Poster for World Food Day, Samoa, sponsored by FAO, Rome.

Stiglitz, J. 2006. Making globalization work. New York WW Norton.

Tuffery, Michel. 2007. First Contact. Art exhibition, cur. Helen Kedgley. Porirua: Pataka.

Walter, Annie and Vincent Lebot. 2007. Gardens of Oceania. Canberra: Australian Centre for International Agricultural Research.

Yo, A. Y. 1995. At the South-east Asian table. Oxford: Oxford University Press. 